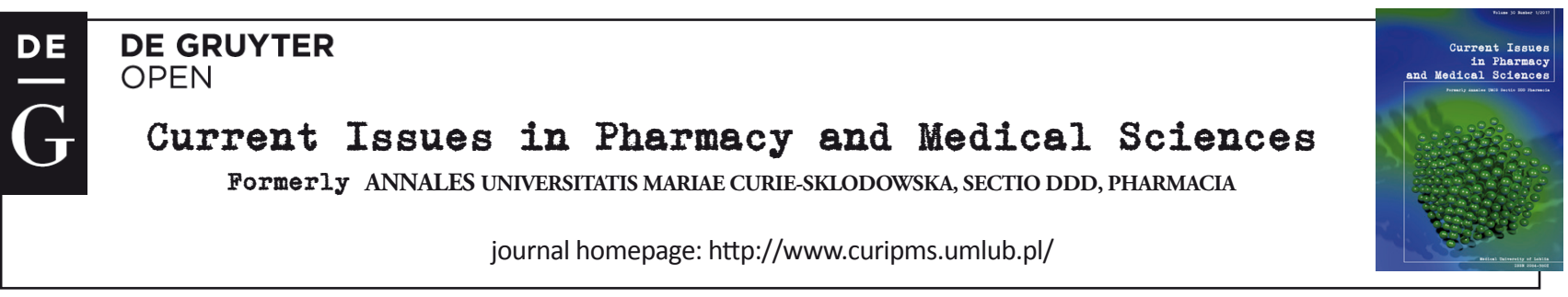

\title{
Mechanical properties of materials used for temporary fixed dentures - in vitro study
}

\author{
Elzbieta Celej-Piszcz, Leszek Szalewski, Przemyslaw Kleinrok*, Janusz Borowicz
}

Department of Dental Prosthetics, Medical University of Lublin, Karmelicka 7, 20-081 Lublin, Poland

\begin{tabular}{|c|c|}
\hline ARTICLE INFO & ABSTRACT \\
\hline $\begin{array}{l}\text { Received } 01 \text { March } 2017 \\
\text { Accepted } 26 \text { May } 2017\end{array}$ & $\begin{array}{l}\text { Objectives. The objective of the research was to define the mechanical properties } \\
\text { of currently marketed temporary filling materials. }\end{array}$ \\
\hline $\begin{array}{l}\text { Keywords: } \\
\text { dental materials, } \\
\text { provisional materials, } \\
\text { flexural strength, } \\
\text { hardness. }\end{array}$ & $\begin{array}{l}\text { Methods. Eight temporary filling materials: Boston, Dentalon, Protemp II, Revotek LC, } \\
\text { Structure 2, Structure } 3 \text {, UniFast LC, UniFast Trad were used to make } 5 \text { samples each } \\
\text { of measurements } 2 \times 2 \times 25 \mathrm{~mm} \text {, in order to define the flexural strength, and } 10 \text { rings } \\
\text { each of measurements } 2 \times 5 \mathrm{~mm} \text {, in order to carry out the Vickers micro-hardness test. } \\
\text { After preparation, the samples were stored in distilled water of temperature of } 370^{\circ} \mathrm{C} \text {, for } \\
7 \text { days. Subsequently, flexural strength and Vickers hardness testing was undertaken. } \\
\text { Results. Composite temporary materials showed considerably better mechanical } \\
\text { properties, both in flexural strength and in Vickers micro-hardness testing. } \\
\text { Conclusions. the best mechanical properties, both in terms of flexural strength, as well as } \\
\text { Vickers micro-hardness test can be observe among composite materials. }\end{array}$ \\
\hline
\end{tabular}

\section{INTRODUCTION}

The prosthetics of permanent filling is one of the most intensively developing branches of dentistry. The usage of permanent prostheses is the most advantageous and the most convenient prosthetic solution for the patient. However, prosthetic rehabilitation using permanent restorations requires several clinical and laboratory activities at different time intervals. During those intervals (from some to up to 20 days), the patient must be given the opportunity to fully function in family and social life. Hence, contemporary prosthodontics definitely demands the usage of temporary crowns and bridges while patients wait for the final solution $[15,16,19,21]$.

As there has been an increase in the number of permanent prosthetic restorations, in recent years, there has been an increased usage of materials for temporary fillings [6].

Materials used for provisional prosthetic restorations are treated in dental materials science as auxiliary materials. The notion 'provisional' may suggest the actual possibility of allowing some kind of carelessness while applying the restoration and less rigorous adherence to prosthetic procedures in comparison to the precision in the constructing of the final solution $[5,19]$. Nonetheless, the lack of applying appropriate protection of the prepared teeth or the use of

\footnotetext{
* Corresponding author

e-mail: kleinrokprzemek@gmail.com
}

unsuitable material for the preparation of provisional filling may lead to the number of iatrogenic complications from the teeth or periodontium and also to the need to perform additional clinical activities. Provisional filling should provide the patient with an active and stress-free functioning in every day life $[6,11,18,21]$. At present, the requirement for materials for provisional filling are very extensive - from both the perspective of dental materials science and dental prosthetics prophylactics. In fact, provisional filling should meet the requirements of fixed filling $[1,7,12]$.

The aim of the study was to determine the strength properties of the materials used for provisional prosthetic fillings. The researches aimed to compare the physico-mechanical properties of 7 materials widely available on the market. The scope of research covered the evaluation of materials in terms of strength parameters made by examining the microhardness and flexural strength. The test results relate to the situation of the laboratory and relate to the characteristics of the material, but the strength parameters can be related to the clinical use of the material.

\section{MATERIALS AND METHODS}

In this paper, the materials that underwent strength tests are listed in Table 1. Separate sets of samples from each material were prepared for the tests. 
Table 1. Materials used in the study

\begin{tabular}{|c|l|l|l|}
\hline & \multicolumn{1}{|c|}{$\begin{array}{c}\text { Material/type } \\
\text { of polimeryzation }\end{array}$} & \multicolumn{1}{|c|}{$\begin{array}{c}\text { Skład/Grupa } \\
\text { materiałowa }\end{array}$} & \multicolumn{1}{|c|}{ Producent } \\
\hline 2 & BOSTON/light curing & composite resin & $\begin{array}{l}\text { ARKONA Laboratorium } \\
\text { Farmakologii } \\
\text { Stomatologicznej }\end{array}$ \\
\hline 3 & PROTEMP II/self curing & acrylic resin & 3M ESPE \\
\hline 4 & PROTEMP 4/self curing & acrylic resin & 3M ESPE \\
\hline 5 & REVOTEK LC/light curing & composite resin & GC EUROPE N.V. \\
\hline 6 & STRUCTUR 2/self curing & composite resin & VOCO \\
\hline 7 & STRUCTUR 3/self curing & composite resin & VOCO \\
\hline 8 & UNIFAST LC/light curing & acrylic resin & GC EUROPE N.V. \\
\hline 9 & UNIFAST TRAD/self curing & acrylic resin & GC EUROPE N.V. \\
\hline
\end{tabular}

In order to determine the flexural strength in 3PB (three point bending test), 5 samples were made of each of the following materials: Boston, Dentalon, Protemp II, Protemp 4, Revotek LC, Structure 2, Structure 3, UniFast LC, UniFast Trad. The samples were prepared in metal moulds measuring $2 \times 2 \times 25 \mathrm{~mm}$. To perform Vickers micro-hardness tests, 10 rings were made of each of the following materials: Boston, Dentalon, Protemp II, Revotek LC, Structure 2, Structure 3 , UniFast LC, UniFast Trad. The discs were of measurements $2 \times 5 \mathrm{~mm}$.

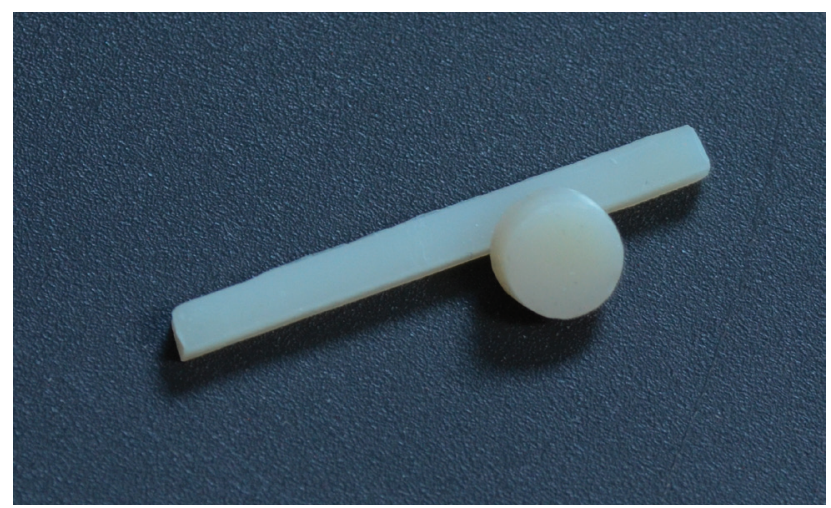

Figure 1. The samples

The metal mould was first lubricated with a thin layer of petroleum jelly on the inside to prevent the material from sticking to the walls of the mould. The tested materials were then placed, and pressed and condensed by raspatories and pluggers. Every sample requiring the use of light was irradiated with Clear Blue LED with a capacity of $1200 \mathrm{~mW} / \mathrm{cm}^{2}$. In so doing, both sides of each sample were irradiated for 20 seconds. All samples were subsequently polymerized with a polyethylene film in order to eliminate an oxygen inhibition layer. After hardening, the samples were removed from the matrix gently so as not to damage the edges. Any possible roughnesses were smoothed away with a Sof-lex (3M ESPE) disc. The samples were then examined carefully to eliminate samples containing air bubbles or other inaccuracies that might have come about through condensation and polymerization. All samples were stored for 7 days from the preparation in distilled water at $370^{\circ} \mathrm{C}$. After this time, the samples were rinsed twice with distilled water and dried. They were then subjected to flexural strength testing and Vickers micro-hardness testing.

\section{The flexural strength test}

The fracture resistance test was performed in a tensile tester Zwick type (Roel), with the support distance of $20 \mathrm{~mm}$ and with the head speed of $0.75 \mathrm{~mm} / \mathrm{min}$, utilizing an initial force of $1 \mathrm{~N}$. The width and thickness of each sample were measured using electronic calipers so as to obtain the most accurate results. The fracture of the sample terminated the test.

The tension determining the flexural strength was calculated from the following formula: $\sigma=3 \mathrm{~F}_{\mathrm{m}} \mathrm{I} / 2 \mathrm{bh}^{2}$

$\mathrm{F}_{\mathrm{m}}$ - maximum force at the time of the fracture of the sample I - distance between supports of $10 \mathrm{~mm}$

b - the width of the sample

$\mathrm{h}$ - the thickness of the sample

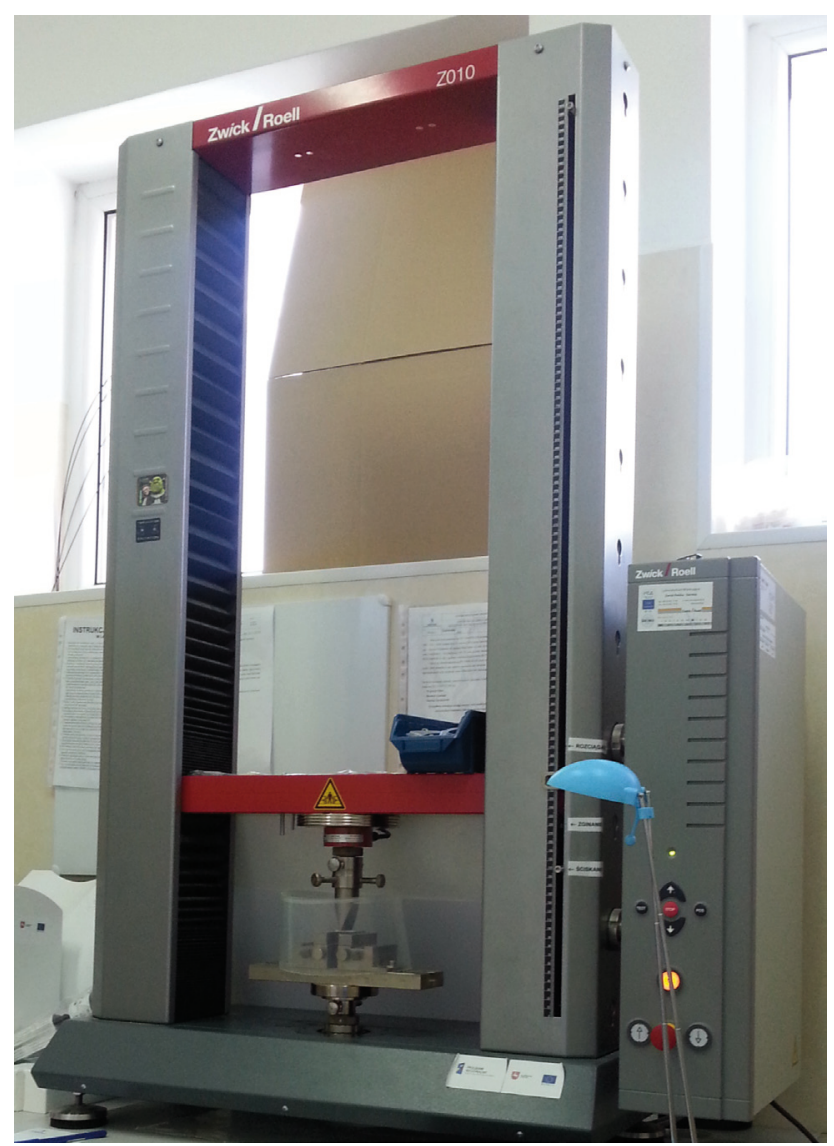

Figure 2. Testing device - flexural strenght

\section{The Vickers micro-hardness test}

Hardness tests were carried out using the Vickers method, with the help of Vickers micro-hardness tester mhp 100, in accordance with PN-EN ISO 6507-1, with a load of $20 \mathrm{~g}$ for 10 seconds. The measurement of the length of diagonal left by the indenter on the surface of the sample was made by examining the surface of the samples under optical microscope Neophot 2. In the experiment, 10 separate indentations were carried out on each sample of each material. The calculations take into account the fact that micro-hardness is proportional to the ratio of the loading force and the surface area of the indentation, the shape of which is taken as a simple pyramid with a square base and the same apex angle as that of the indenter. 


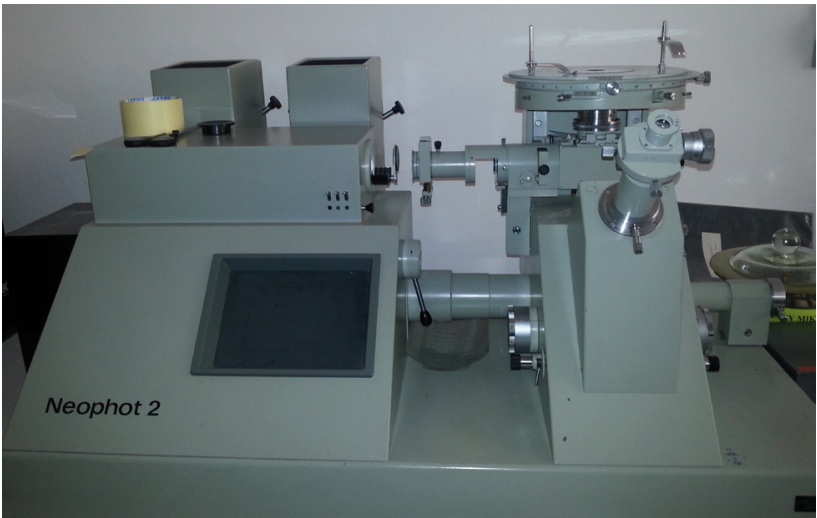

Figure 3. Testing device - Vickers Mickrohardness

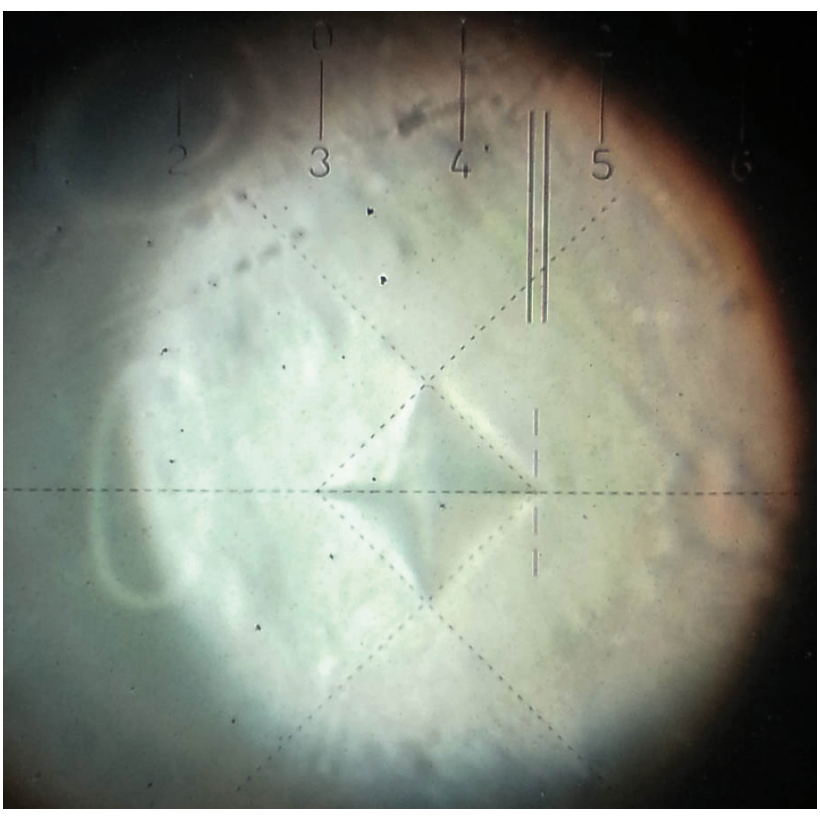

Figure 4. View after microhardeness testing on sample surfac

\section{RESULTS}

The results and statistical analysis are presented in Tables $2,3,4,5$.

Table 2. Flexural strength [MPa]

\begin{tabular}{|c|c|c|c|c|c|c|c|c|c|}
\hline Statistic & $\begin{array}{l}\text { ᄃ } \\
\text { ஸे } \\
\text { ○े } \\
\infty\end{array}$ & $\begin{array}{l}\frac{5}{\sqrt{0}} \\
\frac{0}{\mathbb{J}} \\
\frac{1}{0} \\
0\end{array}$ & $\begin{array}{l}\text { ज } \\
\text { है } \\
\text { है } \\
\text { ơ } \\
\text { 이 }\end{array}$ & 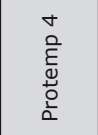 & 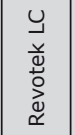 & 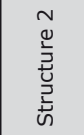 & 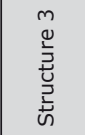 & 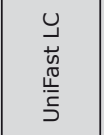 & 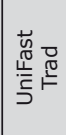 \\
\hline \begin{tabular}{|l|} 
No. of \\
observations \\
\end{tabular} & 5 & 5 & 5 & 5 & 5 & 5 & 5 & 5 & 5 \\
\hline Minimum & 59.5 & 30.4 & 57.3 & 24.5 & 52.8 & 58.4 & 58.9 & 40.4 & 57.1 \\
\hline Maximum & 144 & 49.5 & 77.2 & 51 & 73.1 & 75.5 & 71.1 & 77.5 & 76.9 \\
\hline Median & 92.9 & 37.3 & 64.8 & 49.1 & 67.5 & 72.6 & 68.1 & 60.7 & 67.5 \\
\hline Mean & 99.32 & 37.8 & 66.56 & 43.68 & 66.2 & 68.58 & 65.98 & 56.58 & 67 \\
\hline \begin{tabular}{|l|} 
Variance \\
$(\mathrm{n}-1)$
\end{tabular} & 1066.297 & 60.36 & 55.493 & 121.537 & 66.04 & 52.572 & 24.417 & 229.867 & 62.88 \\
\hline
\end{tabular}

Table 3. Flexural strength. Kruskal-Wallis test

\begin{tabular}{|l|c|}
\hline K (Observed value) & 26.262 \\
\hline K (Critical value) & 15.507 \\
\hline DF & 8 \\
\hline p-value (Two-tailed) & 0.001 \\
\hline alpha & 0.05 \\
\hline
\end{tabular}

Table 4. Vickers microhardness

\begin{tabular}{|c|c|c|c|c|c|c|c|}
\hline Statistic & 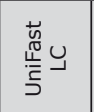 & 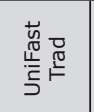 & 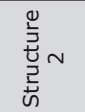 & 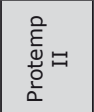 & 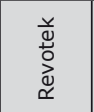 & 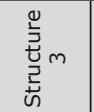 & 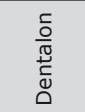 \\
\hline $\begin{array}{l}\text { No. of } \\
\text { observations }\end{array}$ & 30 & 30 & 30 & 30 & 30 & 30 & 30 \\
\hline Minimum & 13.683 & 12.129 & 8.033 & 10.61 & 11.273 & 15.938 & 5.627 \\
\hline Maximum & 20.963 & 30.787 & 32.985 & 22.51 & 27.879 & 38.152 & 13.839 \\
\hline Median & 17.615 & 23.177 & 22.675 & 15.371 & 16.747 & 22.675 & 8.359 \\
\hline Mean & 17.372 & 21.612 & 22.077 & 16.042 & 17.523 & 23.535 & 8.681 \\
\hline $\begin{array}{l}\text { Standard } \\
\text { deviation }(n-1)\end{array}$ & 2.131 & 5.422 & 6.075 & 2.887 & 3.854 & 5.016 & 1.957 \\
\hline
\end{tabular}

Table 5. Vickers microhardeness. Kruskal-Wallis test

\begin{tabular}{|c|c|}
\hline K (Observed value) & 114.222 \\
\hline K (Critical value) & 12.592 \\
\hline DF & 6 \\
\hline p-value (Two-tailed) & $<0.0001$ \\
\hline alpha & 0.05 \\
\hline
\end{tabular}

Statistical analysis was carried out in three stages; firstly, descriptive statistics of the obtained results of the flexural strength were generated, then, normality of the distribution of the obtained results was assessed, finally, the significance of differences between the samples was ascertained.

\section{Flexural strength}

Statistical analysis indicates that with regard to flexural strength measured via arithmetic average, the Boston material showed the greatest flexural strength, while Dentalon showed the least physical strength. Using as a measure, average median, analogous results were obtained. Boston, however, has the greatest variability in the observed results (standard deviation) and the greatest degree of change (the difference between max and min observation). In contrast, Stuctur 3 revealed the lowest diversity of results and the smallest scope of changes within the observed results. Normality of the distribution of the results of each material were tested by Jarque-Beraia and Shapiro-Wilk tests, with the statistical significance alpha $=0.05$. The aforementioned analysis shows that the results obtained for each material are normally distributed. In case of the second test, there was no normal distribution of the results for the material Protemp 4. Accordingly, the so-called non-parametric Kruskal-Wallis test was then applied. The analysis showed 5 errors out of 100 cases, we, therefore, can conclude that the differences are statistically significant.

\section{Micro-hardness}

Statistical analysis of the micro-hardness test was also carried out in three stages. Statistical analysis indicates that via arithmetic average, the greatest micro-hardness was observed in case of Structure 3, and the least micro-hardness was seen in Dentalon. Using as a measure an average median, Unifast Trad showed the greatest micro-hardness, and Dentalon showed the least micro-hardness. At the same time, Dentalon had the smallest diversity of observed results when measured by standard deviation, while the greatest diversity of the results and the 
biggest range of changes within the observed results was seen in the case of Structur 2. Normality of the distribution of the results of each material were tested by Jarque-Beraia and Shapiro-Wilk tests, with the statistical significance $\alpha=0.05$. The analysis showed that the results obtained for each material in the first test have normal distribution. In the case of the second test, there was no normal distribution of the results for the material Structure 2. Accordingly, the so-called non-parametric Kruskal-Wallis test was applied. At the significance level alpha $=0.05$, the null hypothesis was rejected, demonstrating that all samples of materials come from the same population, which means that the differences between materials are statistically significant.

\section{DISCUSSION}

The mechanical properties of provisional restorations are essential for resistance to occlusal forces and the forces triggered during mastication, and, hence, for ensuring the survival of restoration till the time of the final prosthetic reconstruction. The essence of the undertaken endurance tests was to study the materials' mechanical strength, taking into account the two different directions of the main forces to which the actions of the prosthetic restoration in the mouth are exposed to Such work specified at the same time, the force with which the material sample is destroyed, and the hardness (or resistance) to the point forces (interaction effects of concentrated forces that may deform the surface or induce crushing or scratching).

Mechanical strength is a major factor affecting the integrity of the temporary restoration $[1,2,14,17]$. One of the physical properties relevant from the clinical point of view is micro-hardness. This is a property that defines the resistance to scratching. Micro-hardness is the property of the material correlating with the resistance to wear. The advantage of the Vickers method over other methods in case of micro-hardness of dental materials measuring is lack of sensitivity to the imperfections of the material surface after polymerization.

The damage to the temporary restoration (cracking, breaking or material chipping) is troublesome for both patient and dentist. Restoration repair is usually not satisfactory (each repair severely weakens the material), or even impossible, and the preparation of a new restoration unnecessarily takes both the patient's and the dentist's time. Moreover, it increases the cost of treatment $[1,4,8,9,10]$.

In certain clinical cases, it be assumed in advance that the material out of which the restoration will be made should have good strength parameters. Situations that call for high-strength restorations include: a bridge on the side of a large bay, extended prosthetic treatment, inevitability of great forces acting on a bridge, the superior strength of the masticatory muscles in a patient, parafunctions, frequent fractures of the restorations in the past [19].

\section{CONCLUSIONS}

Given the limitations of the test, undoubtedly, the best mechanical properties, both in terms of flexural strength as well as the Vickers micro-hardness test, are observed in composite materials. When choosing the material for temporary crowns, the dentist should know its mechanical properties as it is very important for the durability of the operation; in particular when we foresee the long-time use of temporary work, in case of lateral bridges or in the case of extensive temporary restorations. The selection of the wrong material can cause clinical complications during the prosthetic treatment.

\section{REFERENCES}

1. Ahmad I. (2007) Stomatologia estetyczna: Tymczasowe uzupetnienia terapeutyczne. Elsevier. Chapter in a book.

2. Balkenhol M. et al.: Mechanical properties of provisional crown and bridge materials: chemical-curing versus dual-curing systems. J. Dent. 36, 152008.

3. Balkenhol M. et al.: Provisional crown and fixed partial denture materials: mechanical properties and degree of conversion. Dent. Mater., 23,1574, 2007.

4. Diaz-Arnold A.M., Dunne J.T., Jones A.H.: Microhardness of provisional fixed prosthodontic materials. J. Prosth. Dent., 82, 525 1999.

5. Driscoll C.F., Woolsay G., Ferguson W.M.: Comparison of exothermic release during of polymerization of four materials used to fabricate interim restorations. J. Prosth. Dent., 65, 504, 1991.

6. Fill-in - więcej, niż tylko jeszcze jeden materiał do wykonywania tymczasowych koron i mostów. Mag. Now. Stom. Kerr Focus, 3, 7, 2004 .

7. Gładkowski J., Gontek R.: Wykonanie uzupełnień czasowych z wykorzystaniem chemoutwardzalnego materiału kompozycyjnego Protemp II. Prot. Stom., 66, 326, 1996.

8. Gratton D.G., Aquilino S.A.: Interim restorations. Dent. Clin. North. Am., 48, 487, 2004.

9. Haddix J.E.: A technique for visible light-cured provisional restorations. J. Prosthet. Dent., 59, 512, 1988.

10. Hamza A.T. et al.: The effect of fiber reinforcement on the fracture toughness and flexural strength of provisional restorative resins. J. Prosth. Dent., 91, 258, 2004.

11. Hernandez E.P. et al.: Mechanical properties of four methylmethacrylate-based resins for provisional fixed restorations. Biomed. Mater. Eng., 14, 107, 2004.

12. Kleinrok M. (1995): Zasady wykonania protez stałych - korona lana $i$ licowana porcelaną: Korony i mosty tymczasowe. ZWP Politechnika Lubelska, Chapter in a book.

13. Lieu C., Nguyen T., Payant L.: In vitro Comparison of Peak Polymerization Temperatures of 5 provisional restoration resins. J. Can. Dent. Association, 67, 36, 2001.

14. Lipski T. et al.: Badania niektórych własności fizycznych wybranych materiałów stosowanych do wykonywania mostów tymczasowych. Prot. Stom., 53, 358, 2003.

15. Majewski S.W. (2000): Podstawy protetyki w praktyce lekarskiej $i$ technice dentystycznej: Ogólna charakterystyka podstawowych uzupetnień protetycznych. Wydawnictwo Stomatologiczne SZS-W, Chapter in a book.

16. Majewski S.W. (1998): Protetyka stałych uzupetnień zębowych: Korony protetyczne w praktyce klinicznej. Wydawnictwo SZS-W, Chapter in a book.

17. Manhart J. et al.: Mechanical properties and wear behavior of lightcured packable composite resins. Dent Mater., 16, 33, 2000.

18. Mierzwińska E.: Niektóre aspekty profilaktyki w protetyce stomatologicznej. Prot. Stom., 31, 167, 1981.

19. Rosenstiel S.F., Land M.F., Fujimoto J. (2002): Współczesne protezy stałe: Uzupetnienia czasowe. Czelej, Chapter in a book.

20. Vallittu P.K.: Peak temperatures of some prosthetic acrylates on polymerization. J. Oral. Rehabil., 23, 776, 1996.

21. Wiśniewska G., Majewski S.: Tymczasowe korony i mosty jako element profilaktyki w protetyce stomatologicznej. Mag. Stom., 7, 17, 1997. 